\title{
SKYHAWK, SKYSHIELD, AND THE SOVIETS: REVISITING GANADA'S COLD WAR
}

\author{
ASA MCKERCHER \\ Royal Military College of Canada
}

A N D

\author{
TIMOTHY ANDREWS SAYLE \\ University of Toronto
}

\begin{abstract}
A B S T RACT. For the past two decades, Canadian international historians have largely missed the Cold War, or at least a significant portion of it. Certainly, there has been no shortage of studies of Canadian foreign policy featuring the bipolar struggle, and yet historians have largely confined their attention to Canada's admittedly crucial relationship with the United States, while Canadian-Soviet relations have been ignored. Indeed, in the historiography of Canada's Cold War international relations, the communist powers are largely missing. Hoping to challenge this limited focus, we frame our article around two Canada-US air defence exercises held in 1959 and I96o. While historians have viewed these exercises within the context of Canada's relationship with the United States, we highlight the wider Cold War framework in which Canadian policy was formed. After all, these exercises occurred during the mini-détente of the late I95os and the collapse of the Paris summit in May I96o. As we demonstrate, the failure to take full account of the Cold War is a shortcoming of much of the writing on Canadian international relations, and so we offer an example of the need to take seriously Canada's foreign policy toward the communist bloc.
\end{abstract}

For the past two decades, Canadian international historians have largely missed the Cold War, or at least a significant portion of it, and, as is often the case, what is true for Canada is true for Britain and no doubt other Western countries. Certainly, there has been no shortage of excellent studies of post-1945

Department of History, Massey Library, Royal Military College of Canada, Kingston, ON, Canada, KךK 7B4 asa.mckercher@rmc.ca

Department of History, Sidney Smith Hall, University of Toronto, Toronto, ON, Canada, M5S $3 \mathrm{G}_{3} \mathrm{tim}$. sayle@utoronto.ca 
Canadian foreign policy. Yet, in these works, the Cold War serves largely as a backdrop for Canada's relations with its allies, principally the United States, just as post-war British international history has often been written through the prism of the Anglo-American 'special relationship'. ${ }^{1}$ Moreover, in the flurry of incisive studies examining Canadian interactions with the 'Third World' - a Cold War neologism - the superpower confrontation is overshadowed, understandably, by decolonization and its attendant issues, a reflection of the wider trend among international historians to 'tak[e] off the Cold War lenses' that blinded them to events in the Global South. ${ }^{2}$ Further, several studies of Canada's early Cold War external relations are showing their age and - critically - deal largely with Canada-US relations. ${ }^{3}$ The result is inordinate attention to Canada's admittedly crucial relationship with the United States, and a lack of knowledge regarding Canadian-Soviet relations. The communist powers are largely missing from the historiography of Canada's Cold War. This limited view of post-war Canadian international relations assuredly exists in other Western historiographies.

To be fair, Canadian policy toward the Soviet Union and the People's Republic of China has not been neglected entirely, but these works tend to be either dated, or limited in scope. 4 Furthermore, virtually no literature

${ }^{1}$ Robert Bothwell, Alliance and illusion: Canada and the world, I945-1984 (Vancouver, BC, 2007). On Britain, see Nigel Ashton, Kennedy, Macmillan and the Cold War: the irony of interdependence (Basingstoke, 2002); Richard Aldous, Macmillan, Eisenhower and the Cold War (Dublin, 2005). Admittedly, relations with Western Europe also loom large in post-war British international history.

${ }^{2}$ Matthew Connelly, 'Taking off the Cold War lens: visions of north-south conflict during the Algerian war for independence', American Historical Review, 105 (2000), pp. 739-69; Robin Gendron, Towards a francophone community: Canada's relations with France and French Africa, 1945-1968 (Montreal, QC, 2006); David Webster, Fire and the full moon: Canada and Indonesia in a decolonizing world (Vancouver, BC, 2009); Kevin Spooner, Canada, the Congo crisis, and UN peacekeeping, 1960-1964 (Vancouver, BC, 2009); Ryan Touhey, Conflicting visions: Canada and India in the Cold War world, 1946-1976 (Vancouver, BC, 2015).

3 Reg Whitaker and Gary Marcuse, Cold War Canada: the making of a national insecurity state, 1945-1957 (Toronto, ON, 1996); Denis Stairs, The diplomacy of constraint: Canada, the Korean war and the United States (Toronto, ON, 1974); Lawrence Aronsen and Martin Kitchen, The origins of the Cold War in comparative perspective (New York, NY, 1988), pp. 148-98; Denis Smith, Diplomacy of fear: Canada and the Cold War, I94I-I948 (Toronto, ON, 1988); Robert Teigrob, Warming up to the Cold War: Canada and the United States' coalition of the willing (Toronto, ON, 2009).

${ }^{4}$ On Canada-Soviet relations, see C. A. Ruud, The constant diplomat: Robert Ford in Moscow (Montreal, QC, 2009); A. Balawyder, ed., Canadian-Soviet relations, 1939-1980 (Oakville, ON, 1981); J. L. Black and N. Hillmer, eds., Nearly neighbours: Canada and the Soviet Union, from Cold War to détente and beyond (Kingston, ON, 1989); D. Davies, ed., Canada and the Soviet experiment: essays on Canadian encounters with Russia and the Soviet Union, I9oo-I99I (Toronto, ON, 1994). On Canada-China relations, see Paul Evans and B. M. Frolic, eds., Reluctant adversaries: Canada and the People's Republic of China, I949-1970 (Toronto, ON, 1991); Greg Donaghy and John Hilliker, “Don't let Asia split the west": Canada and the People's Republic of China, 1949-1971', in Documenting diplomacy in the twenty-first century (Washington, DC, 201 1) , 84-99; Greg Donaghy and Michael Stevenson, 'The limits of alliance: Cold War solidarity and Canadian wheat exports to China, 1950-1963', Agricultural History, 
exists on Canada's relations with the Soviet satellites, despite, for instance, the import of Canadian-Polish relations on the International Control Commissions in Indochina. No doubt this oversight stems from language limitations and the lack of access to Russian and Chinese documents. Yet, by ignoring the Second World, Canadian historians have also been neglecting the new Cold War history, which, though it itself neglects Canada, offers important insights into Eastern bloc foreign policy that can inform our own understanding of Canadian actions. 5 Analyses of Canadian Cold War foreign relations are incomplete and there is a need within the field to explore Canada's relations with, and policy toward, the communist bloc powers. ${ }^{6}$ Our prescription with regard to Canada's Cold War is one that we feel should be adopted by international historians concerned with the foreign policy of other Western countries.

Herein, we examine a series of joint Canada-US air defence exercises held between 1959 and 1960. And we do so having purposefully donned Cold War lenses - that is, we try to understand Canadian policy regarding the greater East-West antagonism of the day and not simply the OttawaWashington axis. These exercises, Operations Skyhawk and Skyshield, serve as a focal point around which we demonstrate the need to incorporate a more holistic approach to Cold War Canadian foreign policy that sees beyond the United States and encompasses the USSR. As Robert Ford, a Canadian diplomat and Sovietologist who spent sixteen years as ambassador in Moscow put it, Ottawa's relationship with Moscow 'could never be strictly bilateral, but trilateral'.7 Indeed, by situating Ottawa between Moscow and Washington, we reveal a richer and more complicated history of Canadian foreign policy at the height of the Cold War: as a party to East-West antagonism and an American ally, but as a state concerned by US policy and seeking to make its

83 (2009), pp. 29-5o; Greg Donaghy, 'Red China blues: Paul Martin, Lester B. Pearson, and the China conundrum, 1963-1967', Journal of American-East Asian Relations, 20 (2013), pp. $190-202$.

5 Vlad Zubok and Constantine Pleshakov, Inside the Kremlin's Cold War: from Stalin to Khrushchev (Cambridge, MA, 1997); Aleksandr Fursenko and Timothy Naftali, Khrushchev's Cold War: the inside story of an American adversary (New York, NY, 2007); Vlad Zubok, A failed empire: the Soviet Union in the Cold War from Stalin to Gorbachev (Chapel Hill, NC, 2oog); Chen Jian, Mao's China and the Cold War (Chapel Hill, NC, 2001); Melvyn Leffler, For the soul of mankind: the United States, the Soviet Union, and the Cold War (New York, NY, 2007); Odd Arne Westad, The global Cold War (Cambridge, 2005).

6 Jamie Glazov's Canadian policy toward Khrushchev's Soviet Union (Montreal, QC, 2002) was published too early to take account of much of the new Cold War history. Recently, studies of Canadian cultural diplomacy toward the communist powers have appeared, showing the potential for new, and important, historiographical advances: Graham Carr, "“No political significance of any kind": Glenn Gould's tour of the Soviet Union and the culture of the Cold War', Canadian Historical Review, 95 (2014), pp. 1-29; Kailey Hansson, 'An ancillary weapon: cultural diplomacy and nation-building in Cold War Canada, 1945-1967' (Ph.D. thesis, Queen's University, 2015).

7 R. A. D. Ford, Our man in Moscow: a diplomat's reflections on the Soviet Union (Toronto, ON, $1989)$, p. 91 . 
own determinations about the Soviet Union. For non-Canadianist historians, our case-study adds to the important literature regarding differences between Washington and its allies over the direction of the Cold War, a literature in which Canada is generally absent or is treated as a mere appendix of the United States. ${ }^{8}$ Moreover, our study contributes to a wider understanding of Soviet Premier Nikita Khrushchev's 'courtship of the West' in the late 195os and efforts during this period by Soviet and Western leaders to foster peaceful co-existence in order to reduce tension.9

At first blush, these two air defence exercises would seem to be odd choices with which to make our point. Held in September 1960, Operation Skyshield was meant to test Canadian and American defence systems 'in the most realistic environment possible'. ${ }^{10}$ It marked the first time that the entire North American air defence network had been tested, necessitating the delay or cancellation of 1,3 oo commercial flights while hundreds of 'enemy' bombers simulated a nuclear attack. Subsequent exercises were held in 1961 and 1962; the latter was the last instance where all non-military flights in North America would be grounded until 11 September 2001. The Skyshield exercises are largely unimportant in themselves: taking place at the dawn of the ICBM-age, they were anachronistic from the start. Even so, they were successful demonstrations of Canadian-American co-operation in joint defence. Indeed, the importance of smooth bilateral collaboration was paramount, because in 1959 Operation Skyhawk, a precursor exercise, had been cancelled amidst mutual recriminations between American and Canadian officials, including President Dwight Eisenhower and Prime Minister John Diefenbaker. Hence, Skyhawk has received at least passing scholarly attention as an example of differences between Ottawa and Washington over continental defence and military co-operation. Skyhawk, a recent analysis has contended, 'undermined' Diefenbaker's support for Eisenhower, for the failure to consult with Canada over a military exercise raised doubts about American consultation in the event of an actual crisis. ${ }^{11}$ Analysis of Skyhawk has been confined to its relevance to North American military co-operation. As authorities on this issue note, Diefenbaker's handling of Skyhawk was a 'debacle' and a 'nasty little business' in Canada-US relations, that reflected

${ }^{8}$ E. Bruce Geelhoed and Anthony Edmonds, Eisenhower, Macmillan and allied unity, I957I96I (Basingstoke, 2003). In John Gaddis's remarkable We now know: rethinking Cold War history (Oxford, 1997), Canada receives one mention. In the otherwise comprehensive, three-volume The Cambridge history of the Cold War, 'Canada' appears twice, and in the same chapter: A. Deighton, 'Britain and the Cold War, 1945-1955', in Melvyn Leffler and Odd Arne Westad, eds., Cambridge history of the Cold War (Cambridge, 2010), I, p. 112.

9 Vojtech Mastny, 'Soviet foreign policy, 1953-1962', in Cambridge history of the Cold War, I, p. 325; Willian Taubman, Khrushchev: the man and his era (New York, NY, 2003), p. 400.

${ }^{\circ}$ Christopher Bright, Continental defense in the Eisenhower era (Basingstoke 2010), p. 148.

11 Patricia McMahon, Essence of indecision: Diefenbaker's nuclear policy, 1957-1963 (Montreal, QC, 2009), p. $5^{8 .}$ 
Canadian 'concern with the broad contours of US defence and nuclear policy'. ${ }^{2}$ Yet this focus on Canadian-American military affairs is only half the story.

Beyond continental defence, the Skyhawk incident was reflective of apparent differences between Canadian and American outlook during the Cold War. These joint exercises, then, have not been put into the proper context, namely of Canadian foreign policy toward Moscow. Viewing these operations with reference to the Cold War necessitates examining them within the context of Canadian-Soviet relations in the early Diefenbaker years, from 1957 to 1960 . In the extant literature, Diefenbaker has been portrayed as a one-dimensional cold warrior, whose policies toward the Soviet Union were heavily influenced by Canadians of Eastern European origin. In this telling, when Diefenbaker came to power in 1957 , he viewed foreign policy through political lenses rather than 'in an international perspective', which led him to pursue 'a strategy that was founded more on his own emotional instincts and on his devotion to domestic concerns than on any calculated international objectives'. ${ }^{13}$ Yet examining Canadian actions through the lens of Skyhawk and Skyshield shows that Diefenbaker's Soviet policy - much to the chagrin of officials in Washington - was based on more than domestic political calculations: it responded to the contours of the Cold War. Even Diefenbaker's political calculations were not so one sided as they have been presented, for he and his government were aware of the political value of relaxed tensions with the USSR. The early Diefenbaker period coincided with the 'Spirit of Camp David' and the fleeting détente of the late 1950s; Skyhawk should be seen then against this hopeful background. Skyshield, meanwhile, marked the end of this period, occurring just after the U-2 spy plane incident and the collapse of the Western-Soviet summit process, which had the effect of hardening Canadian foreign policy. Viewing Skyhawk and Skyshield not simply in terms of the well-worn focus on Canada-US relations but through the CanadianSoviet relationship, it becomes clear that the Diefenbaker government's policies were shaped by the tenor of international events and were not based on simple, one-dimensional anti-communism (or anti-Americanism).

\section{I}

John Diefenbaker won Canada's 1957 federal election on a nationalist platform, premised partly on anti-US themes. Yet his policies were driven not by enmity of the United States, but by a concern with close Canadian-American economic ties and their impact on Canada's traditional links with Britain.

12 Sean Maloney, Learning to love the bomb: Canada's nuclear weapons during the Cold War (Washington, DC, 2007), p. 178; J. L. Granatstein, Canada, 1957-1967: years of uncertainty and innovation (Toronto, ON, 1986), p. 111; and Andrew Richter, Avoiding Armageddon: Canadian military strategy and nuclear weapons, 1950-1963 (Vancouver, BC, 2002), p. 97. See also Joseph Jockel, Canada in NORAD, I957-2007: a history (Montreal, QC, 2007), p. $5^{1 .}$

13 Glazov, Canadian policy, pp. 77-8. 
Hence his willingness to deepen the Canada-US alliance by signing Canada onto the North American Air Defence Command (NORAD) - meant to coordinate continental defence against a Soviet bomber attack - within months of becoming prime minister. NORAD was the latest step in joint defence efforts stretching back to the Second World War. Despite the significance of the NORAD agreement, Canadian concerns about the close US-Canada alliance remained. As Diefenbaker explained to Eisenhower in July 1958, there was still a 'wide-spread fear in Canada that they were sacrificing sovereignty by turning their squadrons over to an American General'. ${ }^{14}$ Although one critic of Diefenbaker has complained that he 'became over-sensitized to criticism over sovereignty issues', Canadians, long allied to great powers - or under imperial rule-held deep, understandable anxieties over a lack of control of their own foreign and defence policies. ${ }^{15}$

Against this backdrop of deepening Canada-US defence ties, there developed an expansion of Canada's relations with the communist bloc. In 1954, Ottawa and Moscow had exchanged ambassadors for the first time since 1947, when a major spy scandal had led to the expulsion of Soviet diplomats from Canada. Bilateral relations had expanded further in October 1955 when Lester Pearson became the first NATO foreign minister to visit the USSR, and in February $195^{6}$ with the conclusion of a bilateral trade agreement. However, the Soviet invasion of Hungary that November had put a chill on relations, with Ottawa suspending a newly announced programme of cultural exchanges with the Eastern bloc. Nevertheless, Canadian officials soon sought a thaw. In January 1958, Diefenbaker told Eisenhower that in addition to seeking NATO solidarity he was 'hopeful too that in this year we should be able, in some forum, to make some progress toward a better understanding with the Soviet Government'. ${ }^{16}$ Indeed, responding to entreaties sent by Soviet Premier Nikolai Bulganin to various Western leaders, Diefenbaker, though noting concern over Soviet domination of Eastern Europe, expressed a willingness to expand trade with the Soviets. Moreover, citing the visits of the Soviet hockey team to Canada and of Canadian performers to the USSR, he hinted at a desire to develop further such 'friendly relations'. ${ }^{17}$ At this point, Moscow was concluding cultural exchange agreements with London and with Washington and so in response to Diefenbaker's message, the Soviet ambassador in Ottawa approached Canadian Secretary of State for External Affairs Sidney Smith regarding a similar exchange programme. Smith explained that movement on cultural and scientific exchanges would have to

\footnotetext{
14 Memorandum of conversation, 8 July 1958, Dwight D. Eisenhower Library (DDEL), Ann Whitman File (AWF), international series, box 6, folder Canada.

${ }_{15}$ Maloney, Learning to love, p. 123.

${ }^{16}$ Diefenbaker to Eisenhower, 20 Jan. 1958, DDEL, AWF, international series, box 6, folder Canada.

${ }^{17}$ Diefenbaker to Bulganin, 18 Jan. 1958, Canada, Department of External Affairs (DEA), Supplementary paper $5^{8 / 1}$.
} 
await the outcome of a snap federal election in Canada. ${ }^{18}$ Meanwhile, Khrushchev told a group of visiting Canadian businessman that he would welcome cultural exchanges in addition to more trade, adding: 'I am a businessman too, and if our countries can make a mutual profit, no one will be happier than me.' 19

Following the Canadian election, in which Diefenbaker's Conservatives won a smashing victory, Smith asked the cabinet to approve a general policy to deal with Eastern bloc exchange requests. The policy, he noted, was important especially with Yugoslavia and Poland, where exchanges could 'weaken the ties of these countries to the Soviet bloc'. ${ }^{20}$ Receiving cabinet backing, Smith signed off on a draft exchange programme to be sent to Moscow. It called for scientific missions dealing with mining, ice-breaking, and northern development; cultural exchanges connected to Canada's National Gallery and National Research Council; and hockey. ${ }^{21}$ This slate of possible exchanges differed from a formal cultural agreement along the lines of the US-USSR accord. The reason for this piecemeal approach, Canadian diplomats noted, stemmed from the Canadian federal government's lack of authority over cultural matters and, relatedly, the absence of a federal agency dealing with culture. Perhaps for this reason, the Soviets failed to respond to the draft slate of exchanges, which Ottawa judged to be 'an inexcusable delay'. ${ }^{22}$

Overshadowing any cultural agreement was Khrushchev's effort in November $195^{8}$ to turn Berlin into a demilitarized 'free city' and thereby expel the Western powers. Canadian policy throughout the Berlin crisis, as Canada's foremost international historian has written, was 'hesitant, contradictory, and, above all, ineffective'.23 Despite Diefenbaker's anti-Soviet instincts, it was also far from bullish. As Smith had told the North Atlantic Council, in Ottawa's view, the Western position in Berlin had to be protected, but even so, the West had to be open to negotiation with the Soviets. ${ }^{24}$ As the stalemate wore on, the lack of negotiations was worrisome, with Arnold Heeney, Canada's ambassador in Washington, reminding State Department officials in early 1959 of Ottawa's concern with the Berlin situation's 'potential seriousness'. ${ }^{25}$

In this connection, senior Canadian diplomats welcomed signs that the Soviets were focused on 'an improvement of relations with the West'. ${ }^{26}$ As a

${ }^{18}$ Watkins to Léger, 6 Feb. 1958, Library and Archives Canada (LAC), RG 25 , file 12230-40.

19 'Canadians in Russia', Montreal Star (16 May 1958).

${ }^{20}$ Cabinet conclusions, 19 June 1958, LAC, RG 2, vol. 1898.

${ }^{21}$ Léger to Smith, 27 Aug. 1958, LAC, RG 25, file $12230-40$.

${ }^{22}$ DEA to Moscow, S-34O, 29 May 1959, LAC, RG 25, file 2462-E-4o; Davis to Information Division, 20 July 1959, LAC, RG 25 , file $2727-\mathrm{V}-40$.

23 Bothwell, Alliance, p. 165.

${ }^{24}$ Telegram from the delegation to the North Atlantic Council ministerial meeting to the Department of State, 17 Dec. 1958, Foreign relations of the United States (FRUS), 1958-6o, VIII, p. 213.

${ }^{25}$ Washington to DEA, tel. 469, 26 Feb. 1959, LAC, RG 25, file 50128-4o.

${ }^{26}$ Robertson to Smith, 19 Feb. 1959, LAC, RG 25, file 50128-40. 
means of lowering tension over Berlin, in January 1959 Anastas Mikoyan, first deputy of the Soviet Council of Ministers, had visited Washington, an unprecedented step. As for a visit to Canada, Diefenbaker told officials who enquired about sending an invitation that he 'did not wish to have Mikoyan come' unless a Soviet request was made, in which case 'there would be no way of avoiding it'. ${ }^{27}$ No request was forthcoming. To Diefenbaker, it must have seemed potentially beyond the pale to host a senior Soviet official. Yet that February in welcoming Amasap Aroutunian, the new Soviet ambassador to Ottawa, he noted that Canada was about to appoint a trade commissioner to the Canadian embassy in Moscow and he stressed that he wanted to boost bilateral trade. ${ }^{28}$ Moreover, by early 1959, contacts across the Iron Curtain were all the rage.

In February, British Prime Minister Harold Macmillan visited the Soviet Union. In the view of Canada's man in Moscow, there had been nothing specific to have 'justified a ten day visit' and yet it had been 'useful' in giving Macmillan a sense of Khrushchev, with the 'hopeful result' of a future summit meeting. ${ }^{29}$ En route to Washington to debrief with Eisenhower on his Moscow trip, Macmillan stopped in Ottawa to offer Diefenbaker a rundown of his Soviet tour. In expounding on the state of the Cold War, Canada's prime minister worried, first, over the possibility that improved relations with the Soviets might generate 'a trend toward isolationism' in North America 'manifested in public pressure for the return of American and Canadian forces stationed in Europe'. Such a course would damage Western solidarity and leave Western Europe open to attack. Yet he also worried about 'a considerable intensification of "nationalistic feeling" in Washington, with the result that American officials were intent on rattling the proverbial sabres. His concern in this regard, as he put it, was with 'guarding against any ill-considered move, such as the placing of the Strategic Air Command on an increased state of readiness at a time of tension'. $3^{\circ}$ For Diefenbaker, the risk of miscalculation was high.

Concern over the ramifications of American military policy came fully into play on the question of readiness exercises by the Strategic Air Command (SAC). In 1959, SAC planned Operation Steel Trap, a simulation involving nuclear-armed bombers flying through Canadian airspace to mimic a retaliatory strike against the Soviet Union. This was no small exercise, for SAC was authorized to transport 4,232 nuclear weapons..$^{11}$ The issue of atomic overflights was sensitive in Ottawa, and Canadians of different political stripes had worked to

\footnotetext{
${ }^{27}$ Robinson note, 5 Jan. 1959, LAC, RG 25, file 2462-40.

${ }_{28}$ Robertson note, 4 Feb. 1959, LAC, RG 25, file $2462-40$.

29 Moscow to DEA, D-274, 6 Mar. 1959, LAC, RG 25, file 501 28-40.

$3^{\circ}$ Memorandum of conversation, 18 Mar. 1959, LAC, RG 25, file 50412-40.

$3^{1}$ Memorandum by the chief of staff, US Air Force for the joint chiefs of staff on SAC exercise 'Steel Trap', joint chiefs of staff 20919/403, 24July 1959, Digital National Security Archive (DNSA), doc. NHoo8go.
} 
place careful limits on the American movement of atomic weapons in Canada. ${ }^{2}$ The Canadian government granted permission for an initial period from March to June, and approved two subsequent requests by the Americans to extend the exercise until October and then December of that year. Ottawa's acquiescence masked tension and concern. The Canadians were adamant that no publicity be given to the readiness measures, suggesting Diefenbaker saw political liability in co-operating too closely with the US, even if the exercise was a defence against Soviet bombers. 33 When the initial request for permission came through in March, Canadian officials worried that the exercise might exacerbate the lingering situation over Berlin. Arnold Heeney raised this point with acting Secretary of State Christian Herter and Livingston Merchant, the US under-secretary for political affairs. While the prime minister was willing to permit the exercises because of their military value, Heeney underlined that Washington should realize that real 'anxiety' existed in Ottawa over whether Moscow would view the exercises as being too provocative. 34

Canadian concerns about American provocation were hardly abstract. In April and May, the United States had pressed Canada to agree in advance to an arrangement whereby NORAD forces would go on alert in case the Soviet Union denied Western access to Berlin. The Canadians had no interest in delegating this authority to the American NORAD commander. Ottawa feared a miscalculation could escalate or aggravate the crisis, transforming it from a spat in Europe to a possible global conflagration. The Canadians insisted that both the Canadian and American governments jointly - and not the NORAD commander - would decide whether access to Berlin was blocked before moving to alert. 35 In the Canadian wariness was an implicit understanding that the likely trigger of war was not an insatiable Soviet appetite but miscalculation or error by the superpowers.

In June, when the Americans asked for an extension of Steel Trap, both Diefenbaker and Howard Green - newly installed as foreign minister following Smith's death - expressed doubts about the tempo of these over-flights and emphasized their concerns over sovereignty. A firm supporter of nuclear disarmament and wary of US militarism, Green remarked to Heeney that the Americans 'should be "held down" in these matters' and 'should not be given all that they asked for' ${ }^{3}{ }^{6}$ Nonetheless, permission for Steel Trap was granted; but when it came to Skyhawk, Green and Diefenbaker would hold

$3^{2}$ For background, see Timothy Andrews Sayle, 'A pattern of constraint: CanadianAmerican relations in the early Cold War', International Journal, 62 (2007), pp. 689-795. For American frustrations with these limits, see memorandum of conversation, 12 Apr. 1958, DDEL, Christian Herter papers, chronological series, box 4, folder: Apr. $195^{8 .}$

33 Murphy to Gates, 22 Oct. 1959, DNSA, doc. NHoo897.

34 Memorandum of conversation, 9 Mar. 1959, DNSA, doc. NHoo878.

35 Whisenand to Twining, 2 Apr. 1959, DNSA, doc. BColog6; memorandum of conversation, 5 May 1959, DNSA, doc. BCo1 $25^{1 .}$

$3^{6}$ Heeney memoranda to file, $3^{0}$ June 1959, LAC, Heeney papers, vol. 1, file 14 . 
down the Americans. The issue was not simply about sovereignty, but rather about the possibility of some sort of détente.

In May 1959, a summit of the Soviet, American, British, and French foreign ministers was held in Geneva. The following month, meeting Eisenhower for the opening of the St Lawrence Seaway project, Diefenbaker indicated that he would be glad to host a four-power leaders' summit in Quebec City, site of several wartime conferences between Franklin Roosevelt and Winston Churchill.37 Eisenhower, Macmillan, and Khrushchev all favoured a Quebec summit, with the British prime minister floating November 1959 as a possible date. $3^{8}$ Ultimately, and fatefully, a summit was not held until May 196o in Paris.

In the interim, US Vice President Richard Nixon travelled to Moscow in July, and Eisenhower invited Khrushchev to visit the United States in September. The Soviet leader's visit to North America raised the prospect of a stop in Canada. Hoping to improve Soviet-Canadian relations, Ambassador Aroutunian lobbied hard for an invitation for Khrushchev.39 Canada's cabinet was divided on the issue, but ultimately opted to invite the Soviet leader to Ottawa following his American tour. $4^{\circ}$ As Green told Diefenbaker, this visit would give Khrushchev 'an opportunity to become acquainted with the Western way of life as pursued by a middle power', would give him a demonstration of Canada's independence from the United States, but would also show him the unity of the Western position on key East-West issues. Moreover, a visit might help to cement renewal of the Canada-Soviet trade agreement, which had expired in February 1959. It was also a move favoured by $5^{6}$ per cent of Canadians in a recent Gallup poll, an important consideration for the politically minded prime minister. $4^{1}$ Canada's embassy in Moscow made enquiries about extending a formal invitation to the Soviet leader. However, it proved too late for Khrushchev to accept. $4^{2}$ In the end, Diefenbaker was likely relieved by this result. As a former aide speculated, although a visit by the Soviet leader would have served to cement Diefenbaker's international reputation, domestic ethnic groups' hostility toward the Soviets 'touched a most sensitive political nerve in the Diefenbaker anatomy'. 43

37 Eisenhower to Macmillan, 27 June 1959, DDEL, AWF, international series, box 25a, folder Macmillan, 23 Mar. 1959-30 June 1959 (4).

$3^{8}$ See conversation with the president, 8 July 1959, DDEL, Herter papers, box 1o, folder presidential phone calls 1959; Macmillan to Eisenhower, 3o July 1959, DDEL, AWF, international series, box $25^{\mathrm{a}}$, folder Macmillan, 7/1/59 to $12 / 31 / 59$; letter from Chairman Khrushchev to President Eisenhower, 21 July 1959, FRUS, 1958-6o, x (Washington, DC, 1993), pp. 324-5.

39 Robertson to Diefenbaker, 14 Aug. 1959, LAC, H. Basil Robinson papers, vol. 2, file 12.

$4^{\circ}$ Cabinet conclusions, 14 Aug. 1959 and 18 Aug. 1959, LAC, RG 2, vol. 2745.

$4^{1}$ Green to Diefenbaker, 19 Aug. 1959, LAC, Robinson papers, vol. 2, file 12.

$4^{2}$ Holmes to Green, 24 Aug. 1959, Robertson to Green, 24 Aug. 1959, and Robinson to Robertson, 28 Aug. 1959, LAC, Robinson papers, vol. 2, file 12.

43 H. B. Robinson, Diefenbaker's world: a populist in foreign affairs (Toronto, ON, 1989), pp. $101-2$. 
Although domestic pressures from some Canadians may have tempered Diefenbaker's desire to host Khrushchev, there also seemed to be political benefit from détente. Thus, the prime minister chose moves calculated to support the latter. Regarding the Soviet leader's American visit, he publicly applauded Eisenhower's efforts 'towards the creation of an atmosphere which would facilitate the beginnings of what must be a long and difficult process of negotiation'.44 As for the general issue of a summit, in July Diefenbaker had told Herter that since 'eighty percent' of Canadians favoured a four-power summit 'there would be great disillusionment in Canada if such a conference were not held', for it would mean 'that the possibility of a negotiated solution of difficulties with the Soviet Union had been discarded and that war was all that was left'. The prime minister also used this opportunity to complain of press reports that US military officers had been advocating 'preventive war'. 45 Diefenbaker had voiced similar concerns earlier in the year, and this anxiety came together with support for the tentative détente to scuttle Operation Skyhawk.

Planning for Skyhawk had begun at NORAD in January 1959, with the exercise scheduled to take place on 4 October. Once plans were formalized, US Air Force officials briefed Eisenhower, who gave his approval on 5 August. Six days later, US Defence Secretary Neil McElroy broached the plan with his Canadian counterpart, George Pearkes, while talks between the Federal Aviation Administration and Canada's Department of Transport regarding the closure of airspace to civilian aircraft began on 14 August. Yet in this flurry of activity no one thought to notify Canada's prime minister.

So, in a cabinet session on 26 August, Diefenbaker asked Pearkes how a massive operation necessitating the stoppage of civilian flights was approved without his permission. After Pearkes responded by noting that formal approval had not yet been given, an acrimonious debate ensued, pitting those who felt that military planners 'were assuming too much authority in many fields' against those who believed that, because the defence system was continental in scope, 'Canadian participation was essential'. Another group of ministers contended that the timing of the exercise was unfortunate as it came when 'efforts were being made to lessen world tension'. With Khrushchev soon to visit Eisenhower, such a massive exercise could be construed as an effort 'to show the iron fist'. Those opposing approval won out. The next day, cabinet endorsed a message to Washington stating Ottawa's objection to the planned operation as it could generate public alarm and be 'prejudicial' to building bridges with Moscow. $4^{6}$

44 Canada, DEA, Statements $\mathcal{E}$ Speeches (SESS) 59/28, 8 Sept. 1959.

45 Memorandum of conversation, 11 July 1959, DDEL, White House, Office of the Staff Secretary (OSS), international series, box 2, folder Canada (1).

$4^{6}$ Cabinet conclusions, 26 Aug. 1959 and 27 Aug. 1959, LAC, RG 2, vol. 2745. 
American officials were irate. After a quick round of consultations with Air Force General Nathan Twining, the chairman of the joint chiefs of staff, and Foy Kohler, assistant secretary for European affairs, told Ambassador Heeney that Eisenhower had personally approved the operation because of its military value. American officials, he added, were 'shocked' at the apparent Canadian view that 'we could relax our defenses merely because Khrushchev was going to visit us'. Rather, it was important to negotiate from a position of strength to ensure 'an atmosphere of mutual respect'. Heeney, however, emphasized that given its wide scope, Skyhawk could not be considered a standard exercise; moreover, its timing could indeed 'disturb' Khrushchev's visit. 47 In Ottawa, meanwhile, US Ambassador Richard Wigglesworth failed to secure a change in the prime minister's attitude, despite debating the issue with him for two hours. Diefenbaker made it clear that he was upset because of the late date at which he was made aware of the project, and because many Canadians believed that 'military people, primarily US, make decisions which are shoved down throats of Canadian civil officials'. Furthermore, the operation appeared mainly to be 'sabre rattling'. Wigglesworth rejoined that there were 'dangers of a show of disunity between Canada and the United States' particularly with Eisenhower due to enter into talks with Khrushchev. In his subsequent report on this discussion, Wigglesworth advised that Eisenhower might make a lastditch appeal. As for the prime minister's arguments, the ambassador sensed that Diefenbaker was both sincere in his belief that the exercise 'will make things worse for Khrushchev visit' and correct in his judgement of Canadian public opinion. Thus, Wigglesworth cautioned, the 'implication' for NORAD's future 'could be serious'. $4^{8}$

In reviewing matters with his own officials, Diefenbaker was far more sanguine. To an aide, he remarked that in terms of consultation, 'the blame lay with the Canadian side' with Canada's military having neglected to inform him of the matter until a late date. As for the timing of the exercise, he believed that it was of 'questionable wisdom' vis-à-vis the Khrushchev visit. 49 Recounting his discussion with Wigglesworth for his cabinet colleagues, Diefenbaker informed them that he had emphasized 'the international damage that could be caused by the holding of such an operation at this time'. He added that Canadian officers, not 'fully aware of the importance of civilian control', had 'wrongly assumed' that approval for the exercise would be assured.5 ${ }^{\circ}$ These statements by Diefenbaker make evident his conviction regarding the key aspects of civilian control of the military and of the precarious Cold War peace.

47 Memorandum of conversation, 28 Aug. 1959, FRUS, 1958-6o, vII, pp. $763^{-4}$.

$4^{8}$ Telegram from the embassy in Canada to the Department of State 144, 29 Aug. 1959, FRUS, 1958-6o, vII, pp. $765^{-6}$; Robinson to Robertson, $3^{1}$ Aug. 1959, LAC, Robinson papers, vol. 2 , file 12 .

49 Robinson to Robertson, 31 Aug. 1959, LAC, Robinson papers, vol. 2, file 12.

$5^{\circ}$ Cabinet conclusions, 1 Sept. 1959, LAC, RG 2, vol. 2745. 
With Skyhawk in doubt, certain officials made a final attempt to save it. Fearing a 'major crisis' in Canada-US relations, Heeney suggested to Kohler that Washington drop its stipulation that commercial air traffic be stopped. $5^{1}$ However, given the need to conduct a realistic test, Eisenhower refused to relent on this point. He wrote to Diefenbaker to explain Skyhawk's necessity, and to emphasize that far from being a provocative exercise it would 'provide an essential foundation for serious and, I hope, productive discussions' with Khrushchev because it would let the Soviets know that North America was secure. Reading Eisenhower's letter to cabinet, the prime minister stated that he would continue to oppose a test, a position backed by cabinet. In replying to the president, Diefenbaker cited the likelihood that Canadians would become 'unduly alarmed' by the unusual nature of the planned operation and he reiterated his fear that the Soviets might misinterpret the purpose of the test. He did suggest, though, that he might give his approval to a modified operation avoiding the disruption of civil air traffic. $5^{2}$ This small concession was rejected in Washington on grounds that it would make the exercise pointless. Eisenhower thus sent Diefenbaker a perfunctory message noting that NORAD would postpone the exercise until the following year.53 Skyhawk was dead.

The incident underscored several themes: Ottawa's concern about the influence of the US military; the poor state of civil-military relations in Canada; and Canadian anxiety over Cold War stability undergirded by a hope that diplomatic efforts might resolve tensions. Crucially, Diefenbaker and the Canadians rejected the American assumption that Moscow would only negotiate if the West was in a position of strength. Diefenbaker himself preferred to trumpet the possibility of diplomatic rapprochement rather than defence build-up. Speaking publicly two days after Khrushchev had departed back to the USSR, Diefenbaker praised the American and Soviet leaders for having 'embarked on an historic effort to replace mutual suspicion with mutual understanding'. 'Khrushchev's visit to the United States has been an epochal one', he added, although it remained to be seen if it was simply 'a colossal hoax'.54 Alongside this scepticism, there were some hopeful sentiments in these comments and, reflecting on the Skyhawk issue in November, Diefenbaker explained to his cabinet that there was no doubt that their decision to withhold

$5^{1}$ Memorandum of conversation, 31 Aug. 1959, NARA, RG 59, Bureau of European Affairs, country director for Canada, records relating to military matters, box 2, folder SKYHAWK.

$5^{2}$ Cabinet conclusions, 2 Sept. 1959, 3 Sept. 1959, and 6 Sept. 1959, LAC, RG 2, vol. 2745; London embassy to Ottawa embassy telegram, 1 Sept. 1959, and Ottawa embassy to state telegram, 6 Sept. 1959, DDEL, AWF, international series, box 6, folder Canada.

53 Merchant to Kohler, 7 Sept. 1959, and Dillon to Eisenhower, 11 Sept. 1959, NARA, RG 59, Bureau of European Affairs, country director for Canada, records relating to military matters, box 2, folder SKYHAWK; Eisenhower to Diefenbaker, 15 Sept. 1959, DDEL, AWF, international series, box 6 , folder Canada.

54 Notes for an address by the prime minister, 29 Sept. 1959, LAC, RG 25 , file $2462-40$. 
permission had been correct: Khrushchev was making 'unobjectionable' speeches and it was doubtful that he would be doing so had they allowed Skyhawk to proceed. It was important to co-operate with the United States on joint defence, but the key was to 'balance' co-operation with 'protecting Canada's interests'.55 Howard Green was of a like mind. In his own meditation on Skyhawk, Green postulated that there were 'serious differences' between Canada and the United States when it came to dealing with Russia: the Americans judged that 'it was best to be hard and tough all the time'; Canadians felt the opposite..$^{6}$

The Americans, including Ambassador Wigglesworth, also noted the differing assessments of Moscow made in Washington and Ottawa. Wigglesworth judged that the Skyhawk debacle was the result of several problems including civil-military relations in Canada. But the 'most significant problem' was the 'fundamental divergence of view between the United States and Canada as to how to deal with the Communist world'. In his view, even if Green and Diefenbaker had been consulted on Skyhawk earlier, they would still have cancelled it because of their 'softer approach' to dealing with the Sino-Soviet bloc. 57 Perhaps given his longer experience dealing with Canada, Merchant took a less drastic view of Skyhawk. To a meeting of senior State Department officials, he contended that beyond civil-military tensions in Ottawa, the main reason for the 'fiasco' was the 'lack of appreciation and understanding' at senior levels of Canada's government over the nature of continental defence. Lamenting that Canadian cabinet ministers saw 'NORAD as another U.S. Command' rather than as a joint effort, Merchant proposed arranging both for Canadian officials to visit NORAD and for political advisors to be appointed to NORAD headquarters to advise on political issues. $5^{8}$ Military brass approved the former suggestion, but rejected the latter. While Merchant's view was reasonable, Wigglesworth's was right in that he echoed what the Canadians themselves were saying.

Although Skyhawk had been scrapped, US officials lost no time in planning for a subsequent exercise and they took seriously the questions of civilian oversight and joint consultations. These two factors were central to the request made by NORAD's commander-in-chief that October for Ottawa to permit initial planning of an air defence exercise the following autumn. Not only did the proposal outline an intimate consultation process between the military and civil elements in both countries, but it called for safeguards to ensure that the Soviets

55 Cabinet conclusions, 6 Nov. 1959, LAC RG 2, vol. 2745.

$5^{6}$ Cabinet Defence Committee minutes, 24 Oct. 1959, LAC, RG 2, vol. 2749; memorandum of conversation, 21 Sept. 1959, NARA, RG 59, Executive Secretariat, the secretary's and undersecretary's memoranda of conversation, box 17, file secy's m. of con., 11-23 Sept. 1959 .

57 Wigglesworth to Merchant, 14 Oct. 1959, NARA, RG 59, Bureau of European Affairs, country director for Canada, records relating to military matters, box 2, folder SKYHAWK 1959 .

${ }_{5}^{8}$ Memorandum of conversation, 20 Oct. 1959, FRUS, 1958-6o, vII, pp. 769-71. 
did not feel threatened by the operation. Furthermore, as Pearkes noted in a submission to the Cabinet Defence Committee, Canada retained the right to opt out of the exercise. On 5 November, the Cabinet Defence Committee agreed to begin consultations with the Americans on this request.59 Talks began days later as the United States-Canada ministerial Committee on Joint Defence met at Camp David. A forum for senior officials from both governments to co-ordinate and discuss defence issues, this meeting focused on future air defence exercises. US delegates noted the 'necessity' of a comprehensive test of a continental air defence system that had cost over \$3o billion. As for worry about antagonizing the Soviets, the Americans pointed out that no planes involved in the test would approach Soviet airspace, and that an announcement well in advance of the operation would ensure that Moscow - and the North American public-would not see the test as being timed to affect the outcome of any international developments. Thankful that care was being taken, the Canadian delegates were adamant that civilian oversight of planning be implemented, that joint consultation on the matter be ongoing, and that both governments retain the right to back out of the exercise. As Green emphasized, public opinion in Canada and the world situation were factors that Ottawa would need to weigh before giving final approval. The Americans agreed to these points, and the Canadians then allowed preliminary planning to begin. ${ }^{60}$

Canadians saw positive developments more broadly. In November, Diefenbaker told an audience in Halifax that although the 'basic Soviet position' remained opposed to the West, he saw 'signs of a new spirit' and a 'reduction of world tension' in recent developments such as increased trade, official visits, and Khrushchev's more moderate statements. Such moves were advantageous in terms of encouraging 'the development of more normal societies in the U.S.S.R. and Eastern Europe and gradually to bring them into more normal relationships with the West'. ${ }^{61}$ Halifax hosted another visitor days later: Anastas Mikoyan, who spent a day in the city during a stopover en route to Cuba. His meetings with local grandees and Canada's fisheries minister were judged by Canadian diplomats to be a 'great success from everyone's standpoint'.62 Green also sensed a more positive climate. In October, he told the NATO Council that the Khrushchev visit marked 'a new phase of diplomatic activity'. ${ }^{63}$ In talks with the French foreign minister, Green praised 'evidence of

59 Cabinet Defence Committee minutes, 5 Nov. 1959, LAC, RG 2, vol. 2749; and Cabinet Defence Committee documents D13-59, 21 Oct. 1959, and D23-59, 29 Oct. 1959, LAC, Donald Fleming papers, vol. 127 , file 5 .

6o Canada-US Committee on Joint Defence, record of meeting, 8-9 Nov. 1962, LAC, Robinson papers, vol. 8.10; summary record of the meeting of the US-Canada Committee on Joint Defence, 8-9 Nov. 1959, DNSA, doc. NHo1 179; cabinet conclusions, 1o Nov. 1959, LAC, RG 2, vol. 2745 .

${ }^{61}$ Canada, DEA, SESS 59/41, 14 Nov. 1959.

${ }^{62}$ Feaver to Robertson, 2 Dec. 1959, LAC, RG 25, file $115^{62-111-40 .}$

63 Canada, DEA, SEFS 59/38, 28 Oct. 1959. 
a real relaxation of tension today', with Khrushchev's US visit having 'appeared to be a success'. Expressing the same views to Charles de Gaulle, he added that although it 'was premature to say how long it would last' there was little doubt 'that the West should at this stage take advantage of present Soviet dispositions'. ${ }^{6}$ These were hopeful sentiments capturing the sense of expectation in the lead up to the four-power summit to be held in Paris in May 1960; they rested on the assumption, held by Diefenbaker and Green at the time of the Skyhawk cancellation, that diplomacy would prevail. Green was not entirely Pollyana-ish. At a December NATO summit, he affirmed that 'until the fundamental problems are peacefully resolved we shall need to guard against any temptation to relax our vigilance'. ${ }_{5}$ Then again, speaking about Canadian foreign policy in the House of Commons in February 1960, Green proclaimed inanely that 'in the world today Canada has only friends and no enemies'. ${ }^{66}$ Overall, Canadian policy, by emphasizing negotiation over readiness, contrasted with the American approach to Moscow. As Eisenhower himself observed, Canada's defence posture was 'disturbing'. ${ }^{67}$

In their descriptions of the Soviet Union, Canadian politicians and diplomats often emphasized the positive change in the USSR's leadership since Stalin's death in 1953. In April 1960, Gordon Churchill, Canada's minister of trade and commerce, visited Moscow to renew the Canadian-Soviet trade agreement. To Diefenbaker, he reported that the Soviet leadership appeared to be "'moderates" in contrast with Stalin and his colleagues', whose 'desire for peace and friendly relations was genuine'. Professing to having been 'anti-Russian', he now declared that he had 'so many reservations in my mind concerning American foreign policy' and thought that Canada could play a significant role in reducing international tension. In this connection, he urged Diefenbaker to make his own trip to the USSR. ${ }^{68}$ Diefenbaker had already been considering a trip to Moscow, and had discussed it with the Soviet ambassador. ${ }^{69}$

Hopes that the Soviet Union had changed from its Stalinist ways, and that the Cold War was an aberration-perhaps even one partly caused by faulty American analysis of Moscow's intentions - threatened Skyshield. Despite the preliminary planning, Canadian approval of the exercise was hardly a given. In March 1960, Diefenbaker told Ambassador Heeney that public opinion

64 Paris to DEA, tel. 115 o, 3 o Oct. 1959, LAC, RG 25, file $5^{\text {O } 346-1-40 ; ~ D u p u y ~ n o t e, ~} 3$ o Oct. 1959, LAC, Robinson papers, vol. 2, file 13 .

${ }_{65}$ Statement by secretary of state for external affairs, ${ }_{5}$ Dec. 1959, LAC, RG 25 , file $5^{\text {O } 102-}$ $\mathrm{X}-40$.

66 Canada, House of Commons, Debates, 1o Feb. 196o, p. 930.

67 440th meeting of the National Security Council, 7 Apr. 1960, DDEL, papers as president, NSC Series, box 12 , folder: 440th meeting of NSC.

${ }^{6}$ Churchill to Diefenbaker, 27 Apr. 196o, LAC, Diefenbaker papers, MG o1/VI/846/U56 Churchill Conf.

69 Robinson to Robertson, 14 Apr. 196o, LAC, Robinson papers, vol. 3, file 3; Robinson to European Division, 26 May 1960, LAC, Robinson papers, vol. 3, file 5; cabinet conclusions, 20 May 196o, LAC, RG 2, vol. 2746. 
would be 'unfavourable' to a test as Canadians believed that 'we were yielding too easily to the United States'. He also questioned whether in fact Canada had agreed in principle to participate, a situation he wanted Heeney to clarify. Reviewing the files, Heeney informed the prime minister that both the Canadian and American militaries judged that a test was necessary and that planning had gone ahead based on the Camp David agreement. Barring a major crisis, it was concomitant that Ottawa should participate. Convinced, Diefenbaker promised to raise the matter in cabinet. $7^{\circ}$ Meanwhile, NORAD representatives arrived in Ottawa to brief civilian officials in the Canadian government on the details of the planned operation. The NORAD team also touched on a specific Canadian concern by noting that SAC exercises conducted over the past several years had 'evoked no apparent concern or criticism' in Moscow. ${ }^{11}$ Green, Pearkes, and Hees were briefed several days later. In turn, they then informed cabinet of the intended operation. The subsequent ministerial debate was lengthy and veered over much familiar ground, with several cabinet members decrying Washington's apparent lack of concern 'about the possible implications of such exercises to all peoples of the world', while others lamented that the exercise 'appeared to conflict unnecessarily with the efforts to achieve a détente', especially with the May Paris summit, and all its attendants hopes, on the horizon. There were defenders of the test, however, who emphasized the need both to check the defence system and to prove that money on defence had been well spent. In the end, they decided to permit planning to go ahead, but to withhold formal permission. ${ }^{72}$ As the Canadian embassy in Washington informed the State Department in early May, the Canadian government approved of further planning but would delay a formal decision until June. 73

The cabinet's decision, and the comments by certain ministers as well as by the prime minister, reveal the parlous state of Canadian defence and foreign policy in the spring of 1960 . Senior Canadian military officials were certainly concerned, as was the American president. On 9 May, General Charles Foulkes, chairman of the Canadian chiefs of staff, paid a call upon Eisenhower. Foulkes warned of increasing difficulties ahead thanks to 'excessive confidence' on the part of some Canadians in disarmament initiatives 'and a feeling on their part that too much money is being spent on defense'. Canada, he added, had 'no hostile borders' and so 'air defense constitutes its major activity' and yet it was difficult to convince Canadians of this point. Eisenhower agreed, noting both that 'Canada should be more concerned

$7^{\circ}$ Heeney to Rae, 21 Mar. 196o, Nutt to Heeney, 24 Mar. 1960, Rae to Heeney, 1 Apr. 1960, and Washington to DEA, tel. 892, 5 Apr. 1960, LAC RG 25, file $3-2-2-7$.

$7^{1}$ Washington to DEA, tel. 1062, 22 Apr. 1960, and Nutt to file, 21 Apr. 1960, LAC, RG 25, file $3-2-2-7$; cabinet conclusions, 20 Apr. 1960, LAC, RG 2, vol. 2746.

$7^{2}$ Cabinet conclusions, 26 Apr. 1960, and 28 Apr. 196o, LAC, RG 2, vol. 2746.

73 Memorandum of conversation, 3 May 196o, NARA, RG 59, Bureau of European Affairs, country director for Canada, records relating to military matters, box 2, folder Skyshield 1959-60. 
over attack by manned bombers than should the US' and that it was 'most important that Canada and the US act as solid partners and both make some sacrifices'. Thus, when he hosted Diefenbaker at the White House in June, he planned to 'persuade Diefenbaker to place the facts of life before the people'. The prime minister, Eisenhower continued, 'should jam the hard realities down the throats of his people'.74

But up until May 1960, Diefenbaker and the Canadians had differed with the Americans about the facts. Like others around the world, Diefenbaker believed the upcoming four-power Paris summit offered a real opportunity for defusing the Cold War. Unfortunately, May came with bad news: an American U-2 spy plane was shot down over the USSR. Khrushchev revealed the wreckage, and the pilot, on 7 May at a public ceremony, which Canada's ambassador in Moscow called 'an unhappy occasion for Western diplomats' who witnessed the Soviet leader launch into a verbal tirade against the West.75 As Eisenhower prepared to discuss air defence exercises with Diefenbaker, he noted that the U-2 incident might change Canada's position; he 'humorously interjected' to staff 'that we have already offended the Russians' - the obvious Canadian concern. $7^{6}$

From the downing of the U-2, international events moved quickly. The fourpower summit began on 16 May; two days later, Khrushchev, using the summit as a propaganda platform, stormed out of the conference. The collapse of the Paris summit was a turning point in Diefenbaker's attitude toward the Cold War and marked a change in Canadian policy. Not only were plans for Diefenbaker to visit Moscow cancelled, but Canada's prime minister formally approved Skyshield, a marker of a hardening in Canadian attitudes. 77

The U-2 downing was discussed by cabinet, and ministers concluded that given the extensive espionage activities of Soviet agents inside Canada, the 'U.S. air espionage programme was a necessary part of the defence of the Western world and that really the only crime was to have been caught'. Furthermore, Canadian ministers were upset that Khrushchev had scuttled the summit. $7^{8}$ This was the line that Diefenbaker took publicly. In the House of Commons, he contended that the summit had been 'an opportunity for progress and improvement', and 'it had been the expectation of people everywhere in the world that we were moving into a better era'. Yet Khrushchev had dashed these hopes. The next day in a national broadcast, he asked: 'Why did Khrushchev destroy the hopes of mankind?' The answer, Diefenbaker

\footnotetext{
74 Memorandum of conference with the president, 9 May 196o, DDEL, White House, OSS, international series, box 2, folder Canada (2).

75 Moscow to DEA, tel. 235, 9 May 1960, LAC, RG 25, file 501 28-40.

$7^{6}$ Memorandum of conference with the president, 9 May 196o, DDEL, White House, OSS, international series, box 2, folder Canada (2).

77 Robinson to Robertson, 14 Apr. 1960, and Robinson to European Division, 26 May 1960, LAC, Robinson papers, vol. 3, file 3; cabinet conclusions, 20 May 1960, LAC, RG 2, vol. 2746.

$7^{8}$ Cabinet conclusions, 16 May 1960 and 19 May 1960, LAC, RG 2, vol. 2746.
} 
postulated, was that 'the frightening and sinister cold war, which may now be resumed, has been the traditional Soviet instrument of internal-political control of Russia and its enslaved populations'. Defending Washington by cautioning that now was 'not the time to enter into criticisms or recriminations of our friends', the prime minister proclaimed that Westerners had been shaken from their 'complacency' regarding Soviet intentions.79 This call for Western unity with its corresponding denunciations of the Soviets marked a stiffening in Canadian attitudes. In Washington, American officials had been concerned that 'Canadians see themselves lost between the United States and the USSR.'8o Diefenbaker's speech put Canada firmly in the Western camp of the Cold War.

Appreciative of the prime minister's statements, Eisenhower wrote to Diefenbaker to thank him for his 'forceful gesture on the part of a close friend and ally'. Conversely, meeting the prime minister at a diplomatic reception, Ambassador Aroutunian took him to task for 'making speeches again'. The two men then argued about who bore responsibility for the Paris summit's collapse. ${ }^{81}$ As Dillon emphasized to the National Security Council, Soviet actions 'had considerably modified the "soft" attitude' in Ottawa and it was clear that Green and Diefenbaker 'had had their eyes opened' by Khrushchev. ${ }^{82}$ A brief prepared for Eisenhower ahead of his June meetings with Canada's prime minister highlighted the Canadian attitude of 'excessive caution' toward the East-West struggle, with Ottawa tending 'to attach less weight than we have to the need for ostensible military strength', to give 'greater credence to Communist threats', and to be 'more inclined to worry over suggestions involving risks'. The president was urged to convince the prime minister of 'the desirability of maintaining strong and united defenses' and to secure agreement to Skyshield. ${ }^{8} 3$

Visiting Washington in early June, Diefenbaker indicated to Eisenhower that a decision on Skyshield would come soon, and though he would not commit in the meeting, Canadian officials were quick to reassure the Americans that their prime minister would, eventually, approve the exercise. ${ }^{84}$ After his talks with Eisenhower, Diefenbaker travelled to Depauw University to deliver a convocation address. Rhapsodizing as to whether North Americans had been too optimistic about the prospects for peace, he noted that the collapse of the summit 'may have done a service to mankind' because it had served as a

79 Canada, House of Commons, Debates, 18 May 196o; Canada, DEA, SESS 6o/22, 19 May 1960.

8o $44^{6 \text { th }}$ meeting of the National Security Council, 31 May 1960 , FRUS, $195^{8-60}$, vII, p. $79^{8}$.

81 Eisenhower to Diefenbaker, 25 May 1960, DDEL, White House, OSS, international series, box 2, folder Canada; Robinson to Robertson, 31 May 1960, LAC, Robinson papers, vol. 3 , file 5 .

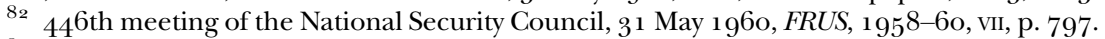

83 Herter to Eisenhower, 'Visit of Prime Minister Diefenbaker', 27 May 1960 and attached briefing papers, DDEL, AWF, international series, box 6, folder Canada.

84 Bryce notes, 17 June 1960 , LAC, RG 25, file $14^{1} 5^{-\mathrm{K}-40}$; 'Meeting with Prime Minister Diefenbaker', memorandum of conversation, 3 June 1960, 4:20 p.m. to 5:45 p.m., Declassified Documents Reference System, CK3100500818. 
reminder of 'the baffling unpredictability of Soviet tactics in international affairs'. Keeping NATO strong and cohesive was vital, a task, he believed, that had been accomplished by the summit's dissolution. It was nonetheless important for the West not to over-react as Khrushchev had done. ${ }^{85}$ After returning from Washington, Diefenbaker sought cabinet approval for Skyshield. As he revealed, he had remarked to Eisenhower that the U-2 incident had 'vindicated' the Canadian government's judgement on Skyhawk. Even so, the present situation was different, a view the cabinet accepted as ministers gave Skyshield their approval. On 24 June, Defence Minister Pearkes publicly announced the government's approval of two other SAC exercises, one of which required the jamming of radar at the Montreal, Toronto, and Ottawa airports for Canadian commercial aircraft for six hours. The other was an extension of overflight exercises for US interceptors carrying nuclear air-to-air missiles. ${ }^{86}$ That September, Skyshield went ahead with no problems. As Green remarked to Herter, the exercise had been 'conducted very successfully' with no public criticism. ${ }^{87}$

Resolving Skyshield was not a total panacea to Canada-US defence relations. As Green's remarks reveal, there was a tension in that he considered the mission a success because it had not excited the backlash he feared. Indeed, an overarching problem, one that would spark a major domestic crisis during which Diefenbaker's government collapsed in 1963, was the issue of whether Canada would take possession of nuclear warheads for several weapons systems geared for both continental defence and the defence of Western Europe. Tensions on this issue were evident at the meeting of the USCanada Committee on Joint Defence, which took place a month after Diefenbaker's Washington trip. Many Canadians, one Canadian delegate pointed out, "feel that Canada is not a part of the nuclear deterrent and that for us to get involved in it in any way is both hazardous and an encroachment on our independence'. The Canadian government therefore was at pains to justify defence spending, particularly for continental defence as there were also concerns 'with respect to Canadian sovereignty'. ${ }^{88}$ Offering Eisenhower a rundown on the meeting, National Security Advisor Gordon Gray described 'the negative view of the Canadians with respect to the Soviet Bloc-Free World struggle' ${ }^{89}$

\footnotetext{
${ }_{5}$ Canada, DEA, $S \mathcal{E} S S 60 / 21,5$ June 1960.

86 Cabinet conclusions, 2 June 1960 and 30 June 196o, LAC, RG 2, vol. 2746.

87 Memorandum of conversation, 20 Sept. 1960 , NARA, RG 84, Ottawa embassy, classified general records, 1959-61, box 224, file international political rel classified 1959-61 CanadaUS.

88 Canada-US Committee on Joint Defence, record of meeting, 12 July 196o, LAC, Robinson papers, vol. 9 .

89 Memorandum of meeting with the president, 19 July 1960, DDEL, White House, Office of the NSA, special assistant series, presidential subseries, box 5 , folder 1960, meetings with president, volume 2.
} 
Seen purely through the prism of defence, Canadian foreign policy appeared weak. However, viewed through the lens of Canadian-Soviet relations, Canadian policy appears firmer. In September 196o, Diefenbaker delivered a UN address that included a strong denunciation of the Soviet colonialism in Eastern Europe. The statement electrified the prime minister's domestic supporters, outraged Soviet officials, earned Diefenbaker praise from Eisenhower, and came to dominate understandings of his policy toward the Soviet Union. $9^{\circ}$ Yet this belligerence came only after the acute international tension of 1960 and after Canada had given Khrushchev the benefit of the doubt up to Paris. As Khrushchev himself noted, Diefenbaker's UN speech was 'less helpful than some of his speeches made earlier in his term' for it 'merely followed [the] American lead'.91 Chill in Canadian policy toward Moscow was apparent after May 1960 and throughout the 'crisis years' of the Cold War, though this did not preclude growing trade ties, notably huge Canadians wheat sales. Even so, Ambassador Aroutunian complained of wanting 'more initiative from the Canadian side' in developing contacts and in warming the bilateral relationship. Canadian diplomats pointed out, however, that 'Soviet-Canadian relations could not develop without regard to the general climate of international affairs.' 92 The early 1960 s were marked by Soviet belligerence in Cold War hotspots from Berlin, to Laos, to Cuba. Canada stayed true to its allies and friends in the Western camp, but remained wary of demonstrations of military might, instead prioritizing diplomacy. 93

\section{I I}

To conclude, Skyhawk and Skyshield serve as markers of Canadian policy, complicating the image of John Diefenbaker's handling of international affairs. Ultimately, they highlight Diefenbaker's political and personal preference for a détente with the Soviet Union and the collapse of that hope in the wake of the U-2 incident. Canadian policy before the Paris summit was not motivated by either anti-Americanism or anti-communism but, according to Green, 'a general impression in Canada that the Americans were too excited and worried about Russia'. American tough talk, defence spending, and military

$9^{\circ}$ Canada, DEA, SESS 6o/32, 26 Sept. 196o; memorandum of conversation, 27 Sept. 196o, NARA, RG 59, Executive Secretariat, secretary and undersecretary's memoranda of conversation, box 17, folder sec memcon: 16-3o Sept. 1960; Moscow to DEA, tel. 537, 5 Nov. 1960, LAC, RG 25 , file $2462-40$.

$9^{1}$ Moscow to DEA, tel. 537, 5 Nov. 1960, LAC, RG 25, file 2462-40.

$9^{2}$ Davis to Robertson, 25 Jan. 1961, LAC, A E. Ritchie papers, vol. 3, file under-secretary's files - memoranda, correspondence, and notes 1961 .

93 The Berlin crisis is a representative example; see Daniel Macfarlane, 'Courting war over a rubber stamp', International Journal, 63 (2008), pp. 751-68; and Timothy Andrews Sayle, 'Canada, NATO, and the Berlin crisis, 1961-1962: "Slow-boil" or "pressure cooker?", International Journal, 68 (2013), pp. 255-68. 
exercises 'alarmed Canadians'.94 Clearly, Canadian politicians felt like Canadian politics were a tug-of-war. On one side, Canadians of Eastern European heritage pressing the government to take a hawkish attitude; on the other, a body of Canadian public opinion concerned about unnecessary conflict. Diefenbaker and Green were the rope.

But beyond the domestic political calculations, the Canadian-American discord over these exercises contrasts what appeared to be different assumptions driving Western policies in the Cold War. Washington and Ottawa judged Moscow differently, and chose policies accordingly. Green, for instance, told Herter in 1960 that 'there was a fundamental difference in the outlook of the two peoples with respect to the Soviet Union'.95 The Department of State, in a private discussion paper for the National Security Council, came to a similar conclusion: Canadians were 'not so fully convinced of the profundity of Communist hostility', and wished to 'avoid acts which might be construed by the Soviets as a threatening gesture or a provocative display of strength, and which might thereby jeopardize the possibility of fruitful negotiations with the USSR on East-West problems'. $9^{6}$ These perceived differences were perhaps indicative of a 'Canadian' and an 'American' view of the Cold War grounded in cultural and intellectual differences between the two polities, with US foreign policy rooted firmly in a messianic ideology. 97 However, as our analysis of the Skyhawk/Skyshield exercises has highlighted, there were variations in the Canadian outlook on the Cold War driven in part by external realities, namely Soviet and US foreign policies.

In the triangular relationship between Moscow, Ottawa, and Washington, Canada and the United States remained on the same axis. But they were also poles apart owing to their differing perspectives on the USSR. If one were to focus only on Skyhawk and Skyshield as incidents within the Canada-US military relationship - as has been the case - then one would miss the important fact that Cold War concerns also drove Canadian policy on these matters. Canadian policy-makers responded positively to the mini-détente of the late $195^{\text {os }}$ but then adopted a harder line toward the Soviets when the summit process collapsed in May 196o. This trajectory-showcasing the importance for Ottawa of Cold War issues and not simply Canada-US issues - has been overlooked. To conclude, our analysis of the Skyhawk and Skyshield exercises took

94 Memorandum of conversation, 20 Sept. 1960, DDRS, doc. CK31 oo688940.

95 Ibid.

$9^{6}$ 'Discussion paper on certain aspects of United States politico-military relationships with Canada', undated [1960], DDRS, CK 3100654201.

97 See Jonathan Fousek, To lead the free world: American nationalism and the cultural roots of the Cold War (Chapel Hill, NC, 200o); H. W. Brands, The devil we knew: Americans and the Cold War (Oxford, 1993); and M. Hunt, Ideology and U.S. foreign policy (New Haven, CT, 1987). And then: J. A. Engel, 'Of fat and thin communists: diplomacy and philosophy in Western economic warfare strategies toward China (and tyrants, broadly)', Diplomatic History, 29 (2005), pp. $445^{-74}$. 
two incidents commonly understood to be solely about Canada-US relations, and demonstrated that, in fact, they also had to do with Canada's policy toward the Soviet Union. As we have demonstrated, there is considerable value for Canadian international historians - and international historians more generally - in donning Cold War lenses. 